Article

\title{
Religiousness and Spirituality in the New Utopian Movements
}

\author{
Javier León Gómez \\ Department of Social Anthropology, University of Sevilla, 41004 Sevilla, Spain; legosum@gmail.com
}

Received: 16 January 2019; Accepted: 28 February 2019; Published: 6 March 2019

check for updates

\begin{abstract}
The aim of this article is the study and analysis of a set of revived utopian communities today, understood as contemporary spiritual heresies from theoretical perspectives close to postmodern critiques. Following ethnographic research over a series of years in different locations across the four continents, this socio-anthropological contribution highlights the characteristics, development and social image of this complex and largely unknown social and spiritual reality. The approach goes beyond the spatial—it includes not only the "being there" and living with the utopian individuals in their own communities for years-but also a temporal dimension, with emphasis placed on their continuity, on the existence of heterodox and heretical groups and communities throughout history. The new ethical critique, environmental problems, and the fear of an imminent sixth extinction guide us in the exploration of new millenarian beliefs emerging from the new spiritual movements born in what is called New Age. A detailed review by these cults-which appear to not follow any recognizable pattern-allows us to understand how some ideas are used in the post-capitalist era or-for the most critical—-the eco-capitalist era. We approach the utopian communities understanding them as key strongholds of a counterculture that has aligned with the times, exploring their symbolic spaces and their idea of progress based, among other premises, on degrowth and voluntary simplicity. This is an approach to today's heresies disguised as modernity. A look at religiousness turned spirituality in utopian movements of our time.
\end{abstract}

Keywords: utopian movements; utopian communities; spiritual heresies; intentional community; counterculture; ecology; New Age; religiousness; spirituality; ecovillages

\section{Introduction}

This work deals with the spiritual phenomena of the New Age in a specific context: the utopian communities of our time. The movement of the Utopian Communities was established in its modern version around the eighties, especially in places such as Scotland, Germany, France, and California. This was a time when the first apocalyptic alarms began in view of the thinning of the ozone layer during the Antarctic winters.

These scientific alarms aimed to prove that humanity was facing a critical problem. There were clear indications and the threats coincided with the Chernobyl catastrophe of 1986. These first warning signs had a response in the new spiritual and social movements, especially in what was known as the Harmonic Convergence, culminating in August 1987. This coincided, seemingly by chance, with the Montreal Protocol, where the signatory countries committed to phase out the production and consumption of ozone-depleting substances (ODS), such as chlorofluorocarbons (CFCs) and halons.

Different world events during this decade, some of them with a catastrophist outlook, triggered the gathering of certain movements in order to somehow face this apocalyptic scene, which will later grow with climate change and global warming. In 1989, when the Berlin Wall was brought down, something else changed in our collective consciousness. Utopian communities begun to appear and extend as 
places of refuge, able to generate alternatives and provide hope, not from the standard ontological nature/culture dichotomy, but understanding humankind as an integral part of nature (Latour 2007), a holistic hybrid far from separations or dichotomies, detached from the basic binary principle. The fall of the Berlin Wall in 1989 somehow broke with this dichotomy, reunifying symbolically two apparently antagonistic worlds.

From an anthropological point of view, there are not many studies whose objectives of investigation were the Utopian Communities, more known in our time as 'intentional communities' or 'ecovillages'. An interest in the study of these new social and spiritual movements (Cornejo 2013), of these "silent minorities" (Cantón 2001), did not develop in parallel to their global growth. Perhaps because in addition to being silent, they also seemed to be invisible during the early eighties (Luckmann 1973), as well as being particularly difficult to access without previous knowledge of their reality or a strong determination to learn. Today, and thanks to new technologies, these movements aim to put their ideals into practice from an alternative communitarian and identitarian perspective, within an extended social network characterized by a vision of utopian values.

An analysis of the construction of this designed identity and this new sense of community from a designed discourse-sometimes from a political ideology and others from a religious-spiritual perspective-, as well as the resulting stigmatization and marginalization they suffer (Prat 2001), are more than sufficient grounds to undertake a scientific and social investigation of this phenomenon. The shared objectives and elements found in these communities such as collective consumption, communitarian culture, and political self-management (Castells 1986, p. 429) are compelling enough to delve deeper into this area of study and understand the influence these movements, and all their ideological apparatus, have on society as a whole. It will likely showcase everything related to the eco-conscious world and its influence on consumerism, fashion, politics, economics, culture, education, and international relations within a context of environmental crisis and, for the most alarmists, an apocalyptical scenario. This is in line with the assumptions that other researchers, such as Buil Blasco (2009, p. 10), have taken into account when approaching the utopian problem:

(a) the current model of growth in Western society is unsustainable, both ecologically and socially;

(b) in order to reach sustainability, new ethics are needed, a change within each individual;

(c) ecovillages aim to be an alternative social model where sustainable values, attitudes, and behaviors hold sway.

Prat (2001, p. 87) refers to utopian communities—he focuses on the strictly religious ones-as microcosms charged with meaning and markedly differentiated from the outside, which brings him closer to the ideal of a more traditional anthropological study: the analysis of a different community, marginal and exotic compared to the researcher's culture. The moment a certain group organizes itself as a community in order to satisfy material, social, cultural, and spiritual needs, a conflict breaks out between this group and the larger, hegemonic society within which it finds itself.

The area of study is wide and thus it is important to differentiate between three types of utopian communities for the purpose of this analysis: (1) subsistence communities; (2) ideological communities; and (3) spiritual communities. In this article we will focus on the third kind, spiritual communities.

\section{Methodology}

After more than ten years as a PhD student at the University of Seville, from 2005 to 2018, I had the opportunity to travel to different countries over four continents in order to undertake a multi-local study as part of an ethnographic project, visiting and living in tens of utopian communities, communes, ecovillages, and intentional communities that devote part of their everyday life to religious and spiritual practice. Although I initially focused on a multi-local study, I later designed a more orthodox research project in two specific locations: the community of Findhorn, in Scotland, and the community of $\mathrm{O}$ Couso, in Galicia, Spain. In the latter, I spent more than four years interacting with utopians from all over the world, involving both co-existence and in-depth interviews. These interviews and all the time 
spent in participative observation led to a revision of the studies on the heretical communities of our times. The study of utopian communities it is not new in anthropology, yet what is novel is the study of their contemporary manifestations. This work is new in the sense that it observes how they have transformed over recent years and how they want to provide answers, from an environmental and spiritual point of view, to the challenges and problems of our time, framed in millenarian perspectives born from new spiritual movements.

Although the phenomenon has developed, there are not many studies about utopian communities, which makes the research challenging from a theoretical point of view. Contemporary studies offering an anthropological or sociological analysis of communities are scarce. From this handful of studies, few or none have a interest in the concept of "utopian community" itself. According to De Marinis (2007), those which deal with the topic of the community from a current perspective are Maffesoli (1990) and his concept of "tribes", Lash (1997) and his "aesthetic communities", Bauman (2003) and his "peg-style communities", or Sluiter (2007) and his "intentional communities". In Spain, Escudero (2007) has worked on "ecoaldeas", Buil Blasco (2009) on "rural communities", and Silvestri and Laura (2015) on the micro-social change in intentional communities. For Silvestri and Laura $(2015$, p. 1), "authors like Sargisson (2010), Von Lüpke (2012), and Meijering (2007) have studied intentional communities and have sometimes defined them as utopian spaces and others as models of sustainability, but always as an answer to the capitalist system". Without disappearing completely, as Putnam (2000) indicates, anthropology has felt the absence of important investigators in last few decades, sometimes rescuing the term 'community' from urban anthropology for studies of neighborhoods with communitarian elements or practices. Research work such as the one carried out by Whyte (1943), Lynd $(1929,1937)$, Gans (1962), Liebow (1967), and Anderson (1991) are a good example of what Wellman (1979) called studies of local or neighborhood communities. The works of Delgado (1999) or Cucó (2004) should also be mentioned, among others. Regarding the communes of counterculture movements that emerged in the sixties and seventies of the last century, noteworthy studies are those by Melville (1975) in the United States, or Gómez-Ullate García de León (2000) and Alonso and Sevilla (2000) in Spain.

The main focus of this research is on the analysis of a series of utopian communities understood as contemporary spiritual and religious heresies. Carrying out the ethnographic investigation over a number of years in different locations, this socio-anthropological contribution highlights the characteristics, development, and social image of this complex and largely unknown social and spiritual reality. The approach is not simply spatial-i.e., it comprises not only the "being there" and living with utopian individuals in their communities for years-but there is also a time-based approach, since emphasis is also put on their continuity, on the existence of heterodox and heretical groups and communities over the years, carrying social marginalization and stigma.

New ethical critiques, environmental crises, and the fear of an imminent sixth mass extinction lead us to the exploration of renewed millenarian beliefs emerging from the new religious movements of the New Age. A detailed review of these spiritual communities, which fail to adhere to any recognizable pattern, allows us to understand how certain ideas are used in the so-called post-capitalist age. We have approached these utopian communities understanding them as key strongholds of a counterculture that has aligned with the times, exploring their symbolic spaces and their idea of progress, which is based, among other premises, on degrowth and voluntary simplicity. This is an approach to today's heresies disguised as modernity. A look at religiousness turned spirituality in the utopian movements of our time.

This article will not go into classical definitions of religion, instead we would like to reveal certain aspects of this spirituality within the frame of the utopian communities whose philosophy of life revolves around phenomenology and the sacredness of nature, and their references to the supernatural or that which belongs in the realm of the strictly sacred (Cantón 2001, p. 19). The main interest is to find a system of identities that shape the personality and character of these new communities and how this personality affects and determines the life of their constituents. With this in mind, this article will deal with three fundamental facets: 
(1) the new spiritual movements; (2) the invisible religious minorities; and (3) privacy in the religious context.

\section{Spiritual Communities and Ideological Communities}

One of the characteristics that builds the identity of utopian communities is their inclination towards markedly political or spiritual stances, within a post-materialist and post-modernist context trying to develop the values of self-expression and within a increasingly humanistic culture (Inglehart and Welzel 2006, p. 4). This differentiation has always existed, even in counterculture movements, with some authors referring to the "wheelie/feelie polarization" (Margolies 1970). The 'wheelies' are the political activists engaged in changing the power structures and institutions, i.e., to fight like the old left, where the system is changed top to bottom; the 'feelies' would be the artists, the psychologists or shamans of the new era, the hippies that, following the tradition of the bohemian beat generation, try to create a new lifestyle bottom-up, privately, changing individuals' consciousness from perspectives of spirituality or human potential (Melville 1975, p. 55). Nowadays, this difference is not so clear, especially due to political movements taking on the ecologist program, which merges and goes hand in hand with the spirituality of the New Age movement and certain libertarian and socialist groups. I have observed in all the communities a syncretic amalgam between the political and the religious-spiritual that affects all aspects of the community, with the common denominator of environmentalism and the post-materialist movements of self-expression (Inglehart and Welzel 2006). The ones that were originally born out of markedly political ideas have now become more spiritual and vice versa, the ones that started off exclusively as spiritual movements now have more of a political penchant thanks to the environmental ideal and its main stake: sustainability.

Before beginning this investigation, I thought that most utopian communities had a marked religious or spiritual ideology, despite the fact that dealing with religion today is sometimes an uncomfortable task (Cantón 2001, p. 31). The community of Findhorn, in Scotland, one of the first communities I based this research on, was a markedly spiritual place, especially in its origins. Following Findhorn I discovered other communities, especially in Spain and Germany, with clear political tendencies. It was only after a long time researching that I realized that this diverse group of communities following the excuse of one or another idea shared a distinctly common sentiment: ecology. Following Dregger (2001), "while some communities are unequivocally oriented towards spirituality and religion, others consider their duty to be political action against the abuses of society. While some place emancipation and therapy high on their priority list, for others the main objective is to live in an environmentally-conscious way. None of these lists of values voids the others; the majority of communities are a mixture of one and the other, yet they establish a different order of priorities". The last part is what I have mostly found, especially in Findhorn and O Couso, so we can say that there are no strictly political or spiritual communities, but rather that there are different priorities where common aspirations come together. For Escorihuela (2008, p. 119):

"throughout history we find thousands of intentional communities of different kinds, which can basically be reduced to two models: religious communities—or religiously inspired-and secular or ideological communities. Interestingly, only the first type have been clearly successful and have continued for generations, up to several centuries in some cases. Of the second type we only have brief testimonies, although their value as a transformational model of society has been very important. Nowadays, the movement of intentional communities-including religious, spiritual, environmental, political, rural, urban communities, etc.- seems to be gathering a new momentum, showing a general tendency to incorporate other key features for sustainability, beyond the first reasons that led people to create these communities. Thus, many spiritual communities are incorporating more and more environmental practices or participating in global political movements. And the same can be said of other communities that, born with a political intention, begin to 
include environmental notions in their approaches and to consider, however slowly, the value of the actual idea of spirituality".

The conclusion seems clear: there is no such dichotomy. There are, however, communities with a more political or spiritual focus, depending on the influence of their founders or their own evolution and interests, but always in constant balance around tendencies, such as ecology, that outweigh the other inclinations.

\section{Conversion and 'The Call' in Utopian Communities}

The detailed study of religious or spiritually-orientated communities, especially when in close proximity to their testimonies, can focus on different facets: those that highlight its practices and morals, those concentrating on metaphysical truths, or those centered around human psychology. In all cases, the origin of many communities has much to do with processes of conversion and with what we will call here 'the call'. Such processes are associated in practice to a "global and radical attainment of a new way of living, drastically separate from the previous form of existence" (Cantón 1998, p. 130). This extraordinary event is spurred by a strong belief able to lead the individual to this drastic change in their life, compelled to become part or build a new community.

However, unlike the earlier communities, the current ones are born looking for some sort of identity, sometimes fragmented by the diverse origins of their members. The fight for this identity is perpetuated with dedicated efforts towards building unity from this diversity, although there are also many similarities with past variants. For Dieter Halbach, in an article called "The rainbow power of community", (Halbach 2005, p. 21), "the rainbow symbolizes the new spirit of self-organized and integrative forms of community-unity in diversity". Yet there exists a clear survival of those who, like their predecessors, felt 'the call' and opted for conversion, entering the ritual of separation from the old, the transitional state of deep crisis and the unconditional adherence to a new life (Cantón 1998, p. 131).

In the analysis of mythological stories, the study of the beginning of the adventure revolves around such a 'call'. It could be identified as a rite of passage (Van Gennep 1986) between a past and obsolete reality and another new sphere of values, which has a lot in common with initiation and conversion processes. There cannot be a separation from the old reality if there is no 'call', a stimulus greater than the individuals themselves that allows them to awake to new thoughts and new intentions. So, the conversion involves a transformation that translates into a new way of life. This transformation many times implies a new way of representing one's life as a narrative and in the form of a conversion testimony (Cantón 1998, p. 132). 'The call' has a lot to do with process of conversion where a progressive or sometimes even drastic regeneration is seen, where grace is received, mystical experience is experienced, protection and strength are acquired, and a process of change is maintained through an interior sense of search and finding. All these are phases, James (2002, p. 263) explains, "that denote the process, sudden or gradual, by which a divided self until that moment, consciously mistaken, inferior or unhappy, becomes unified and consciously happy, superior, and well, as a consequence of holding on to religious realities". Many of these conversions lead to the appearance of a charismatic leader that proclaims the material creation of the imagined or received ideal through grace, thus carrying out the creation of a new utopian community.

The complexity of the process requires us to consider physical, emotional, mental, spiritual, cultural, economic, and social factors. The initial unrest causes an internal motion that brings out passion and desire that-once embraced in the physical contact of the community and the shared daily experience-become emotion and feelings. Here, the 'love bombing' received by part of the members of the community plays an important role (Prat 2001, p. 25; Lofland 1977; Schwartz and Kaslow 1982; Tylor 1982; Galanter 1989). This affection creates a constant sense of fidelity and company that in time becomes a mystical experience of love and union. It creates an affinity of sensitivity and spirit, of complicit silence that represents the communion of the convert and the group, where both group and individual become one. Yet this is a long process that many times leads to rejection or 
abandonment due to its own complexity, not always generating the expected bonding. Sometimes, it is the community itself that rejects the candidate, not completing the subsequent processes of adherence.

The processes of conversion explained from an anthropological perspective (Prat 2001, p. 109) are very common in these communities. Many of their founders and many of the members that come to them refer to this initial 'call'. A clear example of this is one of Findhorn's founders, Eileen Caddy, who felt a clear call through her "conversations with God". In fact, it was what she and the members of the community highlighted the most during my stay in this community. Its founder experienced direct connection with divinity and hence "the miracle", according to its members, of a community like Findhorn.

This 'call' is born within two differentiated frames of human typologies: those who accept the world and those who reject it. Those who accept it usually integrate perfectly into any institutionalized group, trying to transform society and the world from within. This study centers around the second ones, since they intend to transform the world from a radical experience that is sometimes contrary to the common norm and often perceived as heretical. In numerous neo-Christian groups, the metaphor "leave the world" is taken as the synthesis of the mutation that unleashes the new religious affiliation: they are in the world but they are not of the world (Cantón 1998, p. 130). The 'unrest' felt towards the world stirs the sense of wanting to escape and an anguish born out of constant thoughts around the contradictions of the material stimuli of each era. It is the fuga mundi-flight from the world-in the local and spiritual sense that the Church has always preached. It was the philosopher Origen who encouraged the rejection of the world in ancient times: "we must leave it all if we wish to follow the Lord. We must leave it, I say, not as a place, but as a way of thinking; not escaping because of the changes, but advancing in faith" (Colombás 2004, p. 35). It is possible to be out of the world-the poor and new poor, migrants, marginalized groups, etc. who do not accept or reject the world-or against the world-the disenchanted rich, intellectuals, politicians, revolutionaries). Both positions can lead to physical isolation in ashrams, utopian communities, temples, convents; or psychological isolation, such as Jehovah's Witnesses or institutions such as Freemasonry. Either way, this excitement and warmth facing change always causes a sudden crisis that marks a before and an after in the life of the convert, reinforcing their isolation and centering their life around the psychological excitement of the lived experience. The past has died and the present is built in the wake of the 'call' and the structured and permanent conversion (James 2002, pp. 271-73).

Utopian communities are characterized by not encouraging — at least outwardly — the strategies and tactics of the usual proselytism. They do show a thorough and elitist selection of their members, often based on the payment of a considerable amount of money to take extensive courses or "learning" activities that never seem to come to an end. It was important to be able to contrast this to see if it represents an undercover proselytism of sorts or some kind of personalized recruitment. It is crucial to think about how initiation through these courses might be a slow but sure process of conversion, following Prat (2001, p. 189). This process is prolonged over time because the group needs to know whether the person fits perfectly into the philosophy and ways of life of the community. It is also a way of learning about the behavior of the individual, whether they have difficult personalities or may be problematic in the future. In communities such as Sieben Leben in Germany, or Findhorn in Scotland, there is an elaborate and comprehensive process when considering any new member.

Almost none of the groups that I observed or visited-including those that had a distinct religious character such as the Hare Krishna, Brahma Kumaris evangelical groups, Sakya Buddhists, Theosophists, Rosicrucians, Christian Universalists, New Age movements, and an endless number of utopian communities of different kinds and ideology—showed any particular interest in having me join them. I understood that the processes of selecting and proselytizing members are usually quite long and complex. This served as a premise to understand that the social stigma and stereotypes around 'sects' in general —in the social imaginary—often do not correspond with reality. It is not easy to enter certain groups and it is not easy to stay in them once having developed a closer relationship. This is quite opposite to what happens in the collective consciousness. 
The processes of conversion went through an invisible transformation process in utopian communities. If religion does not disappear but is transformed, the same process happens with the process of conversion, a necessity in order for the religious feelings to become apparent esoterically and survive institutions and fads. To understand the unique nature of the conversion, two different kinds of coordinates must be taken into account: sacred time and sacred space. Even though this investigation insists on the sacred dimension of being as a model of conversion and/or initiation, for Cantón "it is hard to accept that religion, as phenomenologists sustain, ultimately refers to an irreducible element: the sacred" (Cantón 2001, p. 14). It is in this subjective space and time where the coordinates of the 'sacred world' are born, a doorway beyond the spatial and the temporal. It is this openness to perceive things—-beyond the physical—-that differentiates the initiated in the community from the rest. This is precisely what is intended in some initiation rituals, to transport the individual to a non-spatial and timeless state in order to connect their inner psyche with the universal psyche, with the infinite cosmos and enter in this way in a new kind of conversion that comes with certain privileges, of which the most obvious is the total belonging to a community. In this process of conversion, the initiated dies to be born again to the new reality, a sacred and sublime reality that will transport them to a superior world. Conversion is the staging of the transcendence that is found in all human beings and in all contemplated object, and it appears covertly in all the movements described here.

This was the aim of the Findhorn community during morning and evening meditations and, above all, when beginning new work - to enter a new state of consciousness and see ourselves as doers at all times of a sacred job. In Findhorn, this process takes hold by means of the ritual of entering the "tube of light", where the active members of a specific section gather in a circle and project an imaginary beam of light from its center, inviting the new member to enter it. If they are accepted, the beam of light will let them enter the center. If not, they are rejected. Prat (2001, p. 118) invites us on a journey through conversions and their different methods within the fascinating world of 'sects'. He puts an end to the clichés of brain-washing and mind control that use "techniques such as intimidation, confusion, forced persuasion, mass suggestion, humiliation, loneliness and isolation, continuous interrogation, overload of insecurities, etc." He goes on to say that "with few exceptions, sociologists and anthropologists that have studied the conversion to religious sects reject the brain-washing model and, on the contrary, favor what we will call causal models of conversion" (Prat 2001, p. 122). Thus, the conversion is not an artifice stemming from psychological pressure on the individual, but a sometimes long and expensive search process by which the individual gains access to the reality of the group or, by default, into the supreme and infinite reality to which the group pays tribute. In the case of utopian communities, the conversion occurs during a long ritualistic process of sustained initiations that happen during the prolonged and expensive courses of "experience". The courses can last up to two years without fully guaranteeing full acceptance into the community.

\section{Postmodern Spirituality. The Influence of the New Spiritual Movements (NSM) in Utopian Communities}

Here, contemporary definitions of religion or spirituality are left aside (Cornejo 2013) when concerning the utopian communities that revolve around phenomenology and its references towards the supernatural or the sacred (Cantón 2001, p. 19). The central interest is to observe the system of identities that constructs the nature and make-up of these new communities and how it affects and determines the members' lives. The New Spiritual Movements (NSM) represent the transformation and/or adaptation of religiousness and spirituality to the new times. Spirituality's lack of territorial nature and timelessness are both equally manifest in today's world. Religiousness tends to occupy all present space and time, and not only institutionally. This implies an inherence with everything human and new forms of adaptation to a globalized world (Cantón 2001, p. 203). Contrary to the New Religious Movements (NRM), the NSM lack an institutional hosts and they are part of a movement that is born from the person, the individual. As Cornejo's (2013) own title points out, we are facing individualism in the new pathways of conversion and a relevance of the New Age as a religious re-learning. 
There is no doubt that many utopian communities are places of refuge that hold at their core a good number of ideologies and beliefs. Additionally, some of them are influenced by or participate in new social movements such as eco-pacifism, multiculturalism, anti-globalism, and/or communitarianism (Antón Mellón 2006). These new contemporary ideologies and political movements influence or mix with those of spiritual nature such as Theosophy, Rosicrucianism, orientalism, yoguism, transpersonalism, human potential, Buddhism, and Christianity, but especially with the new ideas, beliefs, and practices that place an explicit emphasis on the notions of 'spirit' and 'spirituality'. These include at least four currents: the New Age, the Neopaganism, New Religious Movements, and the revival of esotericism (Cornejo 2013, p. 227). Perhaps it would be more accurate to refer to the spirituality of the New Age, which includes the neo-pagan and esoteric movements and excludes the New Religious Movements, which has more in common with previous religiousness than with the new prevailing fashions.

The reality and origin of spiritual utopian communities cannot be understood without a detailed analysis of current NSMs and the discourses emerging from them regarding the private. I use the word "current" because in the 13th century, movements such as the Franciscans were then called "new" religions or "new" religious movements. There is a certain parallelism between some aspects of primitive monasticism and certain religious movements of past and present times. Similar phenomena happened in the past. In ancient Greece there were the Pythagoreans, an extremely heterodox "sect" at the time. Heretical movements throughout history have also been NSM. Perhaps the expression "Spiritual Minorities" would better define this phenomenon. As mentioned, it is not new and it was already present in antiquity. This historical and socio-cultural reality is full of religious innovations and importations, especially from the East. In the process of their development and expansion, according to Vallverdú (2003, p. 412), "the heritage of these New Religious Movements was a strong communitarian spirit, having articulated lifestyles and religious practices oriented towards transcendence and self-realization outside conventional canons. The religious community and the sense of cohesion and unity of social and spiritual goals became a pivotal aspect".

Often-due to carelessness or ignorance-countless movements are overlooked, sometimes caught between the religiousness and secularization of an excessively obscure and inaccessible world. We could talk without fear of other minorities within the minorities that anthropological studies still have not tackled in depth. Some of these minorities are old and some were born in times of post-modernism, globalization, and new technologies, as movements that arose or remain in new utopian communities, able to integrate different antagonisms and apparent contradictions. These new movements, most of them stemming from New Age movements, are often completely unknown due to difficult access to their groups or institutions. As secular examples, noteworthy movements are mostly elitist such as the Freemasons, the Rotarians, or Lions Clubs, with little influence in the Utopian Communities since their members are made to participate in them in an individual and not institutional way (León Gómez 2006). Among the least secular groups are the Theosophist movements, the Spiritists, the Rosicrucians, initiatory orders of all kinds, the Templars, Mystery Schools, among others, with some influence on the utopian communities. If we add to that new Eastern trends, we have an infinite mixture of new movements that would need to be studied and analyzed in detail within this individualistic search of an alternative spirituality to the traditional repertoire of beliefs, rites, and religious institutions (Cornejo 2013, p. 328).

What seems evident is that there seems to be a progressive privatization of the religious sphere, which has gone from officially public to eminently private. According to Gil Calvo (1994), the public religious experience in the classical communal ecclesiastical institution is giving way to another kind of religiousness which seems to be more private, intuitive, and pragmatic. This is seen quite clearly in many communities where there are common practices such as meditations, hymns/chants, or mystical dances. In the majority of cases, spirituality is a completely individual and independent medium that stems from solitary practice in a shared context (Cornejo 2013). This reflection explains the resurgence of this new elitist spirituality—sometimes very narcissistic —in our postmodern societies. Spirituality 
becomes apparent in these new movements, attracting answers to the meaning of the irrational, the infinite, or to the anguish produced by the tragic realization of our limited existence. It does not seem true that humanity has stopped thinking about its mortal uncertainty, but perhaps now it occurs in a more private setting and in little-known and marginal spheres-like utopian communities-and everything they are attempt to ritualize in a shared context.

It is clear to any visitor that this "new religion" is practiced in utopian communities based on a new system of spiritual values with particular characteristics. It is a syncretistic system where ideas extracted from the most varied philosophies and religions are developed-from the West and the East-where neo-pagan currents, ideologies, and esoteric practices intermingle, always leaving aside formal religion, i.e., institutionalized religion. They lack a hierarchical system or even an organized institution, while many communities begin to organize a priori through existing groups (Cornejo 2013, p. 228). Generally, there is no complete institutional specialization where religion or the spiritual assume the form and content of some creed (Luckmann 1973, p. 84). This is why the most common characteristic in such communities is the practice of spirituality as something intimate and private, sharing universal values that enrich one another through the adoption of rites and shared spaces in which to express the new teachings. More than religions, these are systems of religiousness and/or spirituality of private and personal character. We could call them, following Luckmann (1973, p. 81), individual religions.

Utopian communities do not substitute in any case the institution, but are rather suitable spaces to practice this amalgam of ideas, beliefs, and praxis, expressing in the realm of the sacred the inherited tradition of several religious models without ever relying on their institutions. Only in communities of distinct religious nature, especially the Buddhist or Hindu ones that have been emerged in Europe, do they use part of the institution and institutional formality to recreate indispensable aspects of the ritual. All the rest are characterized by the absence of a power elite, administrative bureaucracy or ritual managers within an official model of religion (Luckmann 1973, p. 85). The utopians of our communities are aware that religion-or rather religiousness-tends to be an internal process which, as Wittgenstein (1992) points out, is better described rather than explained. In the interviews, the answers pointed towards a certain confusion regarding the ideological aspect of the matter, yet were very clear concerning its practices. It was made clear at every stage that they did not belong to any particular religion or sect, but that everybody held their own beliefs as something very particular. The explanations may have always seemed excessively uncertain as they did not provide enough data or objective arguments, or a reason for the irrationality of the facts themselves.

It seems appropriate to refer to this new phenomenon as 'invisible religious minorities' in order to describe and analyze a certain type of spirituality on which few studies have been carried out due to the fact that they are particularly new phenomena and, above all, because of their private, closed, secret, discreet character or-as with most of the utopian communities analyzed - of an "exotic" and/or marginal nature. Habermas (1981) and Weber (1998) talk about the private in contrast to the public sphere, with the privacy of the individual being of recurrent importance-just as in the case of the utopians-in spite of their interaction with the group. Privacy is seen as the result of the emancipation of individualism, understanding the loss not of the sense of community or spiritual communion, but rather of the sense of loyalty to a religious institution (Cantón 2001, p. 231). This last definition could be read as a double play on words. Privacy and individualism exist, but they are reinforced in communities where there is a similar and shared interest in privacy. In other words, their members gather and unite in community to develop their individuality and their particular spirituality in a new complicity born from the utopian ideal of freedom, fraternity, and equality. This affirmation may seem contradictory on first inspection, as even though the new spirituality is private and takes pride in it, in some communities it seemed that the group encouraged a kind of spiritual endogamy. These communities are the perfect excuse to practice this private religion, sometimes expressed in small private actions in different places of the community. 
The disenchantment that Weber (1998) praised becomes or transforms into an individualism perfectly acceptable in the realm of communicating with God and the supernatural, thus acquiring once again its religious importance. Nevertheless, there is a drastic change in the relationship with the supernatural or the "natural". If in antiquity God was something alien to humans, that is, something that was outside, in the individual religion today God is inside and in some cases-as in the community of the Human Potential, the philosophy born and inspired from communities such as Esalen, California-God is not only inside us, but we are all potentially gods. Therefore, in the new religion, there is a turn in the conception of God as a distant agent alien to humans-inhabitant of the sky and the cosmos- to a closer, individual god that lives and reigns within us and drives us to fulfill our divine potential. So from the realm of privacy, there is an effort to instill in the individual certain values and ideas foreign to society and above all, with many subtle nuances that often escape classical studies. These are, themselves, ideas and philosophies that run parallel to and/or distant from society, as the social factor disappears and the interaction between individuals is done in private, without the mediation of any institution. This is why these separate and restricted philosophies and ideals try to shape humanity by following its own desires or sympathies with the supernatural. We are, without the slightest doubt, witnessing a new transformation of the relationships between the human-and the natural that is within it—and God—or the supernatural of the infinite. For utopians, these are three manifestations of the same thing: the human (potentially gods), the natural (gods of nature), and the supernatural (universal gods).

Discrete communities are a way of universal sociability. They have existed throughout history in all places, sometimes called secret societies. Simmel (1986) placed them in the context of human sociability and presented them as another resource in any organized communicative relationship. In order to understand them, Simmel (1986) begins with the analysis of secrecy, discretion, friendship, and marriage. For him, secret societies-always being self-aware-are the opposite of instinctive communities. Thus, the typical socialization patterns are accentuated in those societies where their sociological features are the quantitative increase of other kinds of more general relationships. They are, therefore, a privileged reflection of the features of the society where they are inserted. According to Simmel (1986), these features appear as the establishment of a circle of separation between the members and their surroundings (a profane world versus a sacred world in the case of some communities). This occurred above all through their own rituals—initiation rituals during daily activities, collective meditations, personal or group dialogs with the 'devas' of nature, the streams of light, etc.- and the progressive protection of the center of such a circle by means of the constant and progressive initiation of their members; establishing their sociological independence as an association through selfishness and the internal solidarity of the group; and the de-individualization or depersonalization of the members that is clear, above all, in their lack of responsibility regarding their acts as a group.

Religious societies-and consequently the communities studied here-are social constructs (Berger 1981) sheltered by the systematic search for answers to most of humanity's questions. Although religious phenomena are easy to describe through their social manifestations, in this case it is more difficult. This is the reason in most cases religiousness goes unnoticed for researchers, who center the investigation in clearly identified phenomena. This is why delving deeper in their knowledge and their internal logical is to understand a reality that seems invisible to the investigation. To go deeper into their private spirituality - that which is not of public use nor is it openly manifested-takes us closer to this new phenomenon that once again breaks down the myth of secularization that is very present in utopian communities (Cantón 2001, p. 204). It is difficult to understand how a member of a community relegates their usual religious practice to the most intimate privacy. Are we perhaps witnessing the new hermits of the 21st century? We see practices such as yoga (mainly hatha yoga, raja yoga, agni yoga, and jnana yoga)—now so fashionable in our society—or other methods of Eastern tradition, taking place in the most absolute individuality. People, feeling increasingly isolated and lonely, look for group affiliation in a confusing subjectivity, where supposedly superior and invisible 
entities guide the capacity of the individual and the group to reach the ethical and moral goals they all pursue.

\section{The Invisible Spirituality. Revitalization Movements, Disenchantment, Secularization, and Millenarianism in Utopian Communities}

As we investigate the processes of utopian conversion, there is a realization that in the philosophy and acts of such communities there are also mechanisms-already depicted by anthropology-which could be included in the so-called revitalization movements. For Wallace (1956, p. 278), "these are deliberate, organized, and conscious efforts of the members of a society for the construction of a more satisfactory culture". This conclusion seems initially clear, but after careful investigation it becomes evident that the members of the community are in fact organized under an invisible philosophy or religion, only perceived when deepening into it. The individual tends to transform their identity crises or lack of satisfaction with the model in which they live into an image that aims to reduce the pressure caused by this frontal clash. This leads to a need to adjust to the new image, which causes a deep and determined effort to change. If this effort is translated to a group or community, then we refer to revitalization movements (Wallace 1956, p. 266). Revitalization is born from the tireless search for the model of an ideal society. Together with the images of paradise depicted in almost all cultures, the revitalization of society and culture constitutes the most ancient form of utopian thought. Manuel and Manuel (1984) affirm in this regard that the images of paradise and the millennia are a source of inspiration for utopian thinkers. Both have a religious origin, because utopian thought maintains a unique relationship with religion despite, as Kumar (1987) expresses, religion is concerned with the other world while the interest of utopia lies in this world (Ramiro Avilés 2002, p. 193). This last statement is not quite accurate in many communities where both worlds are completely integrated.

It is easy to frame utopian communities within the characteristic network of the New Age as a movement of revitalization. They are characterized by the need to save the world from the plague of our insatiable humanity. Their methods of salvation are immediate action in the practical things of life, such as work, dwelling, education, politics, and general well-being. The materialization of this revitalization for change is approached by means of local solutions with a global impact. In many communities it is accompanied consciously or unconsciously by ideas of salvation and/or millenarian philosophies. The utopian movements of salvation-where new religions emerge with strength in search of hope for a better world-are an important basis for these currents. Millenarian movements are part of this and they are continuously current due to the constant threat of the end of the world as an argument for the belief in a better world, preferably somewhere else or even in the New Land. In anthropology, they have been studied within the movements of acculturation.

Talmon (1979) and Harrison (1984) are right when they state that "the term millenarian is not used nowadays in its limited and specific historical sense, but typologically to characterize the religious movements that await an imminent, total, and earthly collective salvation" (Ramiro Avilés 2002, p. 199). Many utopian communities of our days await this collective salvation here and now, so they apply certain appropriate conditions for that to happen immediately. However, our utopians intend to bring the New Earth into this reality, building the utopia day by day without waiting for it to arrive miraculously or catastrophically; hence why it is more accurate to place them within movements of revitalization. According to Wallace (1956), nativism, revivalism, millenarianism, messianism, cargo cults, or utopian communities are terms encompassing different forms of revitalization movements. These movements are frequently accompanied by the wish to go back to a past time, to restore a golden age, to bring about a previous state of social virtue (revivalism); to expel the foreign causers of a present situation (nativism); the generalized rejection of foreign peoples and cultures (colonialisms); the existence of a country free from evil; the arrival of a Messiah, arrival of the millennial, the ancestors with a cargo, etc. These beliefs that dominate a society - their own mythical dreams-do not constitute by themselves an isolated movement but are found throughout all time and space. 
The combination of an environmental, communitarian movement with a social and cultural dimension and the spiritual dimension could be understood almost as a new invisible religion within a philosophy where Earth or Gaia is a living being able to feel and answer our daily irresponsibility. Thus, the eco-village movements are, according to their members, a responsible answer in the face of a greater and increasingly unsustainable aggression that tries to change the mistaken approaches of a sick and deranged society. This idea resembles in almost every aspect the movements of revitalization that desire a better society in a better world. Utopian communities are able to give answers to this primordial disenchantment of the human being. They intend to be the stewards of this new world, far from the dystopian world in which we live. They are pioneers, an avant-garde whose aim is to save the planet from an inevitable catastrophe, an end of times that is nearer and closer every day.

Gil Calvo (1994, p. 173) reveals how the Weberian theory (also the Marxist and Freudian) inspired the idea that the secularization of modern society was the result of an irreversible process of rationalization. However, we see how society escapes capitalist rigidity with new forms of beliefs and symbolic manifestations, which he himself calls "a process of increasing re-enchantment". Thus, according to the author, "we cannot talk of secularization of the modern culture but of the consecration of the profane". From there, he provides an excellent description of the emergent result of the process of religious modernization, understanding religiousness from an open and wide point of view he describes political religiousness-both activist and contemplative-as well as narcissist religiousness-also activist and contemplative. There is no better example than what happens in utopian communities. For Estruch (1994, pp. 278-79), "contrary to what the apostles and militants of secularization affirm, my thesis is that all disenchantment of the world supposes and implies at the same time the emergence of new forms of re-enchantment, that religion does not disappear but transforms, that ours is an era of religious crisis: but crisis in the sense that religious metamorphosis is happening, not in the sense of its abolition". From an intellectual point of view, secularization (Estruch 1994) implies the marginalization of religion by keeping it in un-scientific, magical or residual pockets, associating it to supposed phases of infra-development of the human being. This seriously stigmatizes the social and cultural side of the religious field, making it marginal and ignoring "the emphatic statement that secularization serves as a smokescreen to ignore the emergence of new religious manifestations" (Estruch 1994, p. 275).

Not only is there a new approach to religious-spiritual realities but-even from a secular perspective-they are considered as new millenarian movements. In fact, contemporary utopian communities would be like small Noah's arks, protected in mountains and valleys from the imminent ecological disaster. They are like shuttles that will serve as lifesavers when "the wave arrives", to use a common expression from the New Age movements. For economists such as Latouche (2009), the future is bleak. He predicts the sinking of Western civilization in three waves: by 2030, exhaustion of natural resources; by 2040, atmospheric contamination, poisoning of the air, water and earth; and in 2060, desertification and famines. One of the fathers of the theory of degrowth as the only viable option, also openly rejecting the possibility of sustainable development, is pessimistic regarding our future. Yet, is it simply a pessimistic view? Is this perhaps a new millenarian movement? Are we really at the end of an era that will only worsen with climate change and the ecological crisis?

\section{Conclusions}

This has been an attempt to be in culture while looking at culture (Clifford 2001), navigating our own and others' narrative analyses, intuiting the influences of this phenomenon and broadening its profiles and boundaries - not only from a temporal perspective, but also a spatial, emotional and psychological one, loaded with transcultural trails. In this work, somehow, we have freed ourselves from the obligation of having to become taxonomically honorable. We have been free to allow it grow organically, without being completely subdued by ideas inherited from our own discipline (Geertz 2003, p. 65). This freedom has had and has its own limitations, its own biases. In this context, we have been able to clearly see in these social experiments the efforts of distilling the advance guard 
of ideas that wish to change the world, this time not 'against the system' (Gómez-Ullate García de León 2000, p. 368), but in a peaceful and calm way, more in favor of building a better world. The first conclusion is that this is a naive and outdated vision. Utopians are not pioneers trying to put into practice everything that can create a better world, a more complete and harmonious civilization. They strive but they fail because the avant-garde of the material improvements come from the world they reject. From renewable energies and eco-houses to the horizontal and fair distribution of resources, cooperation and mutual support, collaborative economies, or voluntary simplicity turn out to be ideas and models that end up failing. The human being, the utopian and non-utopian, is trapped in our time, in this 'liquid society' —in the words of Bauman (2003)—from which it cannot escape.

The community, or the idea of community, always appears to be something docile, innocent, good. It is something that always gives a good impression. A company or society as a whole can be bad, but not the community. In our collective imaginary, the community is something seemingly warm, a comfortable and friendly place. In the community we can also count on mutual support. There will always be somebody that can help us, which is why the word community evokes everything we miss in our individualistic and solitary lives of the city. In the collective imaginary, the community evocates security, aplomb, and confidence, and represents another idea to refer to this lost paradise to which we want to return with all our being (Bauman 2003). In the end, the utopians are feverishly looking for the ways that will take them to this remote idea of community. Ultimately, they miss the traditional community we lost and try to reproduce it in thousands ways without much success. This is why their bets are seen as a continuous experiment, knowing that everything is in constant revision and knowing that almost every attempt will end up in failure. In contrast to the counterculture movements, contemporary utopians embrace the idea of opening to the world and take part in its improvement. Not against what already exists but facilitating tools and visions in favor of it. The slogan of the community of O Couso lets us know about this intention: "to make of a good world a better world". This is, no doubt, a naive position, blatantly a failure looking at the more optimistic statistics on social deterioration and the ecological imbalances of all kind. This ingenuous vision would wish, ultimately, to be a lighthouse of hope. Yet what has been seen over these years is that it is simply a genuine failure, as the ecovillage movement it is not even able to carry out its main purpose: to create a community. One thing is the idealized image of a lost community and a very different matter is a real community, the one that is lived in on a daily basis in our individualistic palaces. A real community requires strict obedience, commitment, and responsibility. It provides safety in exchange for our freedom. It is true that in communities like Findhorn or Los Portales you might stop paying rent, a mortgage, and for light, water, and food. But this material security has a price: freedom. Somehow, to reach material security, they mortgage their individual freedom. This is a great utopian deception-or the great challenge-; it is unlikely that the dispute between freedom and safety, between individuality and community, will be resolved.

However, beyond the material subsistence and its shared ideal, there is the spiritual practice. It is difficult to understand how a member of a community keeps their usual religious practice to the most private of spaces. We see practices such as yoga—now so fashionable in our society-or other Eastern practices like meditation being carried out in the most absolute individuality. People-more and more isolated and alone-look for group affiliation in this confusing subjectivity, where supposedly superior entities guide the potential of the individual and the group to reach the ethical and moral goals they all pursue. It was complex to unveil that behind the philosophy of many communities there exists a hylozoist belief. The belief and its structure are there-everywhere-but it is invisible. It seems to be a hidden variable that structures everything that happens there. An organized whole behind a kind appearance: like a Sole Living Being with a sense of purpose.

Everything that is created in a community has a reason, responding to a superior intelligence. Yet it happens to be a reserved variable — esoteric — only for the initiated. This hidden esotericism between vegetable gardens and eco-homes, reserved only for the most curious or committed, has certain similarities with modern physics. Hylozoism - a pre-Socratic term that thinks of nature as an animated 
whole, i.e., all matter has life and intelligence-is very popular among different New Age beliefs systems that permeate the creation of many communities and ecovillages, who base their raison d'etre on the conservation and protection of nature.

It is useful to dive deeper into these spiritual oddities that contemporary modernity offers us more and more often and that have so much influence on today's utopian communities. If we settle with the old ideas of religion we are overlooking what reality is projecting onto our societies. If the study of the fashionable NRM if the eighties and the nineties was a focus enlightening religious anthropology for years, the new century must take us closer to the new spiritual fashions or new spiritual movements (NSM), which have progressively changed and they themselves have modified in some ways how humans relate to the transcendental or infinite. Anthropology needs to update their perspectives and views regarding the religious and spiritual.

Almost all of them-based on individualistic postmodernism and its progressive emancipation, on new technologies and the need of isolation and serenity in such a hectic world-find a perfect refuge in utopian groups, where it is possible to combine that individuality and privacy with a certain group-like approximation far from dogmas, rigid structures, or any other enforced idea. Religious and spiritual emancipation enjoys a healthy space in communitarian contexts and causes a increasing number of people to approach in search of sharing these interests without to many gimmicks or a set of institutionalized beliefs.

Funding: This research has received no external funding.

Conflicts of Interest: The author declares no conflict of interest.

\section{References}

Alonso, Antonio Manuel, and Eduardo Sevilla. 2000. El discurso ecotecnocrático de la sostenibilidad. Edited by I. en Bárcena, P. Ibarra and M. Zubiaga. Desarrollo sostenible. Un concepto polémico. Bilbao: Universidad del País Vasco, pp. 40-66.

Anderson, B. 1991. Imagined Communities. London: Verso.

Antón Mellón, Joan. 2006. Ideologías y movimientos políticos contemporáneos. Madrid: Tecnos. Beatrice Kesler, Amsterdam: Aksant Academic Publishers, pp. 254-63.

Bauman, Zygmunt. 2003. Comunidad en busca de seguridad en un mundo hostil. Madrid: Siglo XXI.

Berger, Peter. 1981. Hacia una teoría sociológica de la religión. Barcelona: Kairós.

Buil Blasco, Maite. 2009. Sostenibilidad en pequeñas comunidades rurales. Ph.D. thesis, UAB, Barcelona, Spain.

Cantón, Manuela. 1998. Bautizados en fuego. Protestantes, discursos de conversión y política en Guatemala (1989-1993).

La Antigua: Centro de Investigación Regionales de Mesoamérica, Plumsock Mesoamerican Studies, Vermont, EE. UU.

Cantón, Manuela. 2001. La razón hechizada. Teorías antropológicas de la religión. Barcelona: Ariel.

Castells, M. 1986. La ciudad y sus masas. Sociología de los movimientos sociales urbanos. Madrid: Alianza.

Clifford, James. 2001. Dilemas de la cultura. Barcelona: Gedisa Editorial.

Colombás, García M. 2004. El monacato primitivo. Madrid: Biblioteca de Autores Cristianos.

Cornejo, Mónica. 2013. El individualismo en los nuevos itinerarios de conversión: La relevancia de la Nueva Era como re-aprendizaje religioso. In Religio in labyrintho. Madrid: Escolar y Mayo Editores.

Cucó, Josepa. 2004. Antropología urbana. Barcelona: Ariel.

De Marinis, Pablo. 2007. Teorías sociológica sobre la comunidad. Buenos Aires: Seminario de la Facultad de Ciencias Sociales de la Universidad de Buenos Aires.

Delgado, Manuel. 1999. El animal público. Barcelona: Anagrama.

Dregger, Leia. 2001. Eurotopia-Directory: Intentional Communities and Ecovillages in Europe. Bandau Poppau: Ökodorf Sieben Linden.

Escorihuela, José Luis. 2008. Se hace camino al andar. Del individuo moderno a la comunidad sostenible. Córdoba: Nous Editorial.

Escudero, Francisca Ruiz. 2007. Iniciativas innovadoras de desarrollo rural sostenible: Estudio de caso de las ecoaldeas. Ph.D. thesis, Universidad de Córdoba, Córdoba, Spain. 
Estruch, Joan Coordinador. 1994. El mito de la secularización. Edited by R. En Díaz, S. Giner and F. Velasco. Formas modernas de religión. Madrid: Alianza.

Galanter, M. 1989. Cults: Faith, Healing, and Coercion. New York: Oxford University Press.

Gans, Herbert J. 1962. The Urbans Villagers. New York: Free Press.

Geertz, Clifford. 2003. El surgimiento de la antropología posmoderna. Barcelona: Gedisa.

Gil Calvo, Enrique. 1994. Religiones laicas de salvación. In Formas modernas de religión. Edited by R. Díaz-Salazar, S. Giner and F. Velasco. Madrid: Alianza Editorial.

Gómez-Ullate García de León, Martín. 2000. Contracultura y asentamientos alternativos en la España de los '90. Un estudio de antropología social. Ph.D. thesis, Universidad Complutense de Madrid, Madrid, Spain.

Habermas, J. 1981. Historia y crítica de la opinión publica. Barcelona: G. Gili.

Halbach, D. 2005. The Rainbow Power of Community. In Eurotopia-Directory: Intentional Communities and Ecovillages in Europe. Edited by V. Peters and M. Stengel. Bandau Poppau: Ökodorf Sieben Linden, pp. 21-38.

Harrison, J. F. C. 1984. Millenium and Utopia, in Utopias. Edited by Alexander Gill. London: Duckworth, pp. 61-66. Inglehart, Ronald, and Christian Welzel. 2006. Modernización, cambio cultural y democracia: La secuencia del desarrollo humano. Madrid: CIS.

James, William. 2002. Las variedades de la experiencia religiosa. Barcelona: Ed. Península.

Kumar, Krishan. 1987. Utopia and Anti-Utopia in Modern Times. Oxford: Basil Blackwell.

Lash, Scout. 1997. La reflexividad y sus dobles: Estructura, estética, comunidad. In Modernización reflexiva. Política, tradición y estética en el orden social moderno. Edited by Ulrich Beck, Anthony Giddens and Scott Lash. Madrid: Alianza Editorial.

Latouche, Serge. 2009. La apuesta por el decrecimiento. Barcelona: Icaria.

Latour, B. 2007. Nunca fuimos modernos: Ensayo de antropología simétrica. Buenos Aires: Siglo XXI.

León Gómez, Javier. 2006. Entrevista a un masón: Perspectiva Antropológica de una realidad ignorada. Madrid: Editorial Séneca.

Liebow, Elliot. 1967. Tally's Corner. Washington, DC: Little Brown.

Lofland, J. 1977. Promoting Affect: Warmth and Permissiveness. New York: Irvington Publishers.

Luckmann, Thomas. 1973. La religión invisible. El problema de la religión en la sociedad moderna. Salamanca: Ediciones Sígueme.

Lynd, Robert. 1929. Problems of Being Objective. Chicago: University of Chicago, Social Research Council.

Lynd, Robert. 1937. Middletown in Transition. New York: Harcourt, Brace.

Maffesoli, Michel. 1990. El Tiempo de las Tribus. El declive del individualismo en las sociedades de masas. Barcelona: Editorial Icaria.

Manuel, Frank Edward, and Fritzie Prigohzy Manuel. 1984. El pensamiento utópico en el mundo occidental. Madrid: Editorial Tauros.

Margolies, Rick. 1970. On community building, Alternate society. In The New Left: A Collection of Essays. Boston: Priscilla Long.

Meijering, L. 2007. Intentional communities in rural spaces. Tijdschrift Voor Economische. Sociale Geografie 98: 42-52.

Melville, Keith. 1975. Las comunas en la contracultura. Barcelona: Editorial Kairós.

Prat, Joan. 2001. El estigma del extraño. Un ensayo antropológico sobre sectas religiosas. Barcelona: Ariel Antropología.

Putnam, R. D. 2000. Bowling Alone. The Collapse and Revival of American Community. New York: Simon and Schuster.

Ramiro Avilés, Miguel Ángel. 2002. Utopía y derecho: El sistema jurídico en las sociedades ideales. Madrid: Marcial Pons Editor.

Sargisson, L. 2010. Friends Have All Things in Common: Utopian Property Relations. British Journal of Politics and International Relations (BJPIR) 12: 22-36. [CrossRef]

Schwartz, Lita Linzer, and Florence W. Kaslow. 1982. Conversion Techniques. Jewish Social Studies 43: 1-10.

Silvestri, Lombardo, and María Laura. 2015. El propósito de vida en la Comunidad Intencional: La transformación personal para el cambio micro-social. Ph.D. thesis, Universitat Autònoma de Barcelon, Barcelona, Spain.

Simmel, Georg. 1986. El secreto y la sociedad secreta, en Sociología I. Estudios sobre las formas de socialización. Madrid: Alianza Universidad.

Sluiter, Thomas. 2007. Intentional Communities: Creating Alternative Lifestyles in Search of a Better World. Master's Thesis, Vrije Universiteit Amsterdam, Amsterdam, The Netherlands. 
Talmon, Yonina. 1979. Milenarismo. Enciclopedia Internacional de las Ciencias Sociales. Madrid: Editorial Aguilar. Tylor, B. 1982. Loving. London: Nineteenth Century.

Vallverdú, Jaume. 2003. El agente humano. La dimensión socioinstitucional de la religión. In Antropología de la religión: Una aproximación interdisciplinar a las religiones antiguas y contemporáneas. Edited by J. C. Autuori, E. A. Piera and G. M. Cabrillana. Zaragoza: Editorial UOC, pp. 401-72.

Van Gennep, Arnold. 1986. Los ritos de paso. Barcelona: Taurus.

Von Lüpke, Geseko. 2012. Ecovillages: Islands of the Future? RCC Perspectives 8: 73-78.

Wallace, Anthony. 1956. Revitalization Movements. American Anthropologist 58: 264-81. [CrossRef]

Weber, Max. 1998. Ensayos sobre sociología de la religión. Madrid: Editorial Taurus.

Wellman, B. 1979. The Community Question: The Intimate Networks of East Yorkers. American Journal of Sociology 84: 1201-31. [CrossRef]

Whyte, W. F. 1943. Street Corner Society. Chicago: University of Chicago Press.

Wittgenstein, Ludwig. 1992. Lecciones y conversaciones sobre estética, psicología y creencia religiosa. Barcelona: Ediciones Paidós.

(C) 2019 by the author. Licensee MDPI, Basel, Switzerland. This article is an open access article distributed under the terms and conditions of the Creative Commons Attribution (CC BY) license (http:/ / creativecommons.org/licenses/by/4.0/). 